\title{
Poemas 2014
}

Karen Bonilla Corrales

\section{I}

No me atraen tus silencios, tus palabras atrapadas en la garganta, ni tus voces ahogadas por prejuicios.

No me desvelan tus ojos cerrados, tu ceño fruncido, ni tu cabeza complaciente de arriba hacia abajo, ni tus lágrimas reprimidas por mi mano, ni tu rostro multicolor lleno de complicidades, arrepentimientos y falsos perdones.

No me atraen tus manos obedientes y sumisas que se ajustan a mis reproches, ni tus rodillas doblegadas en mis altares.

No me gusta ser el victimario del miedo, por el mismo miedo de poder haber sido la víctima.

\section{II}

No soy fruta exótica de un paraíso "descubierto" y luego saqueado, ni mi cuerpo es un tambor que retumba con sus golpeteos bruscos y perdidos.

No tengo la silueta de muñecas de porcelana: me nutro de la madre tierra y no de complejos consagrados.

No llevo sombreros tropicales, ni sonrío para complacer.

Tampoco callo por obligación, ni asiento por temor.

No trago "grueso" por pudor o virtud, ni crucifico mi rostro por rituales.

Me visto con la sangre indígena y afrocaribeña derramada en mi identidad.

No soy la que me dicen que debo ser, ni siento ganas de serla.
Quiero caminar desnuda sin prejuicios dérmicos, sin pagar el precio de pecados y temores ajenos,

sin llorar la rabia sarnosa de una conquista aún adeudada.

No estamos inexploradas ni ocultas: su corta visión nos cegó también, y nos ató también.

\section{III}

Tantos intentos vanos por visualizar de verde lo que ahora es gris.

Intentos de llevar vida a los rincones asfaltados

que ahora lloran para ser adornados, pero sigue siendo eso: un adorno de colección dominguera,

traído de una feria como artículo exótico.

Por más luces y ventanales grandes, el sol no va a iluminar esa farsa de progreso.

IV

Ya no puedo fingir que no pasó nada, cuando la cruz que traigo se hace cada vez más y más pesada.

Cuando tu mirada me reprocha el pasado y me condena.

Cuando me haces sentir culpable de tus crímenes, de tus miradas y de tus gestos.

Cuando tus silencios se atraviesan en mi garganta y me estrujan la voz.

Cuando tus pensamientos enredados me consumen y me llevan en tus laberintos 


\section{V}

Entre cascadas vislumbro tu silueta, entre los musgos húmedos descubro tu sexo, tu boca.

Encuentro tu palabra entre el rocío.

No quiero tenerte, sino estar contigo.

No es saberme tuya, sino que comprendes mi libertad.

Porque el no verte se me hace eterno, pero el no reconocerme en tus pupilas aumenta esta añoranza de estar con vos, para no estar conmigo.

¡Qué mal negocio! Tengo tu soledad, pero no tu compañía...

\section{VI}

Me hiere tu cuerpo sudoroso de placer, tus ojos cerrados de gozo, tu virilidad sobria y erecta.

Me duele tu fuerza corporal sobre la mía, tu ir y venir sobre la sábana.

Cuando tus silencios se atraviesan en mi garganta y me estrujan la voz.

Cuando tus pensamientos enredados me consumen y me llevan en tus laberintos.

\section{VII}

Tengo miedo

miedo de pensarte y sentirte

miedo de extrañarte y soñarte

miedo de verte en mi memoria y no poderte

sacar

miedo de olerte en mí

miedo de enamorarme de vos

como ya lo hice.

\section{VIII}

¿Qué quiero?

Quiero mirarte, y que mi mirada te encuentre en tus rincones solitarios.

Quiero olerte, y que tu olor me acompañe durante tus ausencias.

Quiero escucharte, y escuchar nuestra complicidad en el silencio.

Quiero tocarte, y tener la certeza que al tocarte puedo sentirte y sentirme.
Quiero sentirte, porque me gustás libre y quiero también poder ser yo libre, a pesar de vos. Quiero amarte, y descansar en la certeza de que me amás también.

Eso quiero.

\section{IX}

Estamos y no estamos, ¿qué clase de acuerdo tenemos en común?

Nos vemos y el mundo cae a nuestros pies, gozamos de los besos y los abrazos, de las respiraciones agitadas, del cabello atravesado entre los labios, de los gemidos y las caricias extenuantes, mas cuando nos vamos, una completa desconexión se interpone, no te conozco, ni me conoces.

No recuerdo tu aroma, ni tu rostro, ni tu nombre.

No te extraño, ni te pienso, ni te siento.

No me acuerdo de vos, ni de nuestros encuentros furtivos.

Pero te miro de nuevo y la ausencia de tantos días se borra.

Y me recuerdo con vos, mi amante ausente.

\section{Luna}

Mirá esa luz que se mete por tu ventana, cómo llena de claridad tu habitación y la recorre centímetro a centímetro.

Asomate al balcón y descubrí a aquella mística compañera que te ayuda a confesar entre las sábanas mi cuerpo desnudo sobre el cual posás tu lengua y te reclama en soledad.

Asomate al balcón.

La consejera de tus noches de lujuria en las que me entregás más que un beso está allí, afuera, cómplice, como todas las noches, envidiosa de tu entrega, de nuestra entrega, de esas noches en las que levantás tu mirada y todavía me llevás en tus pupilas. 


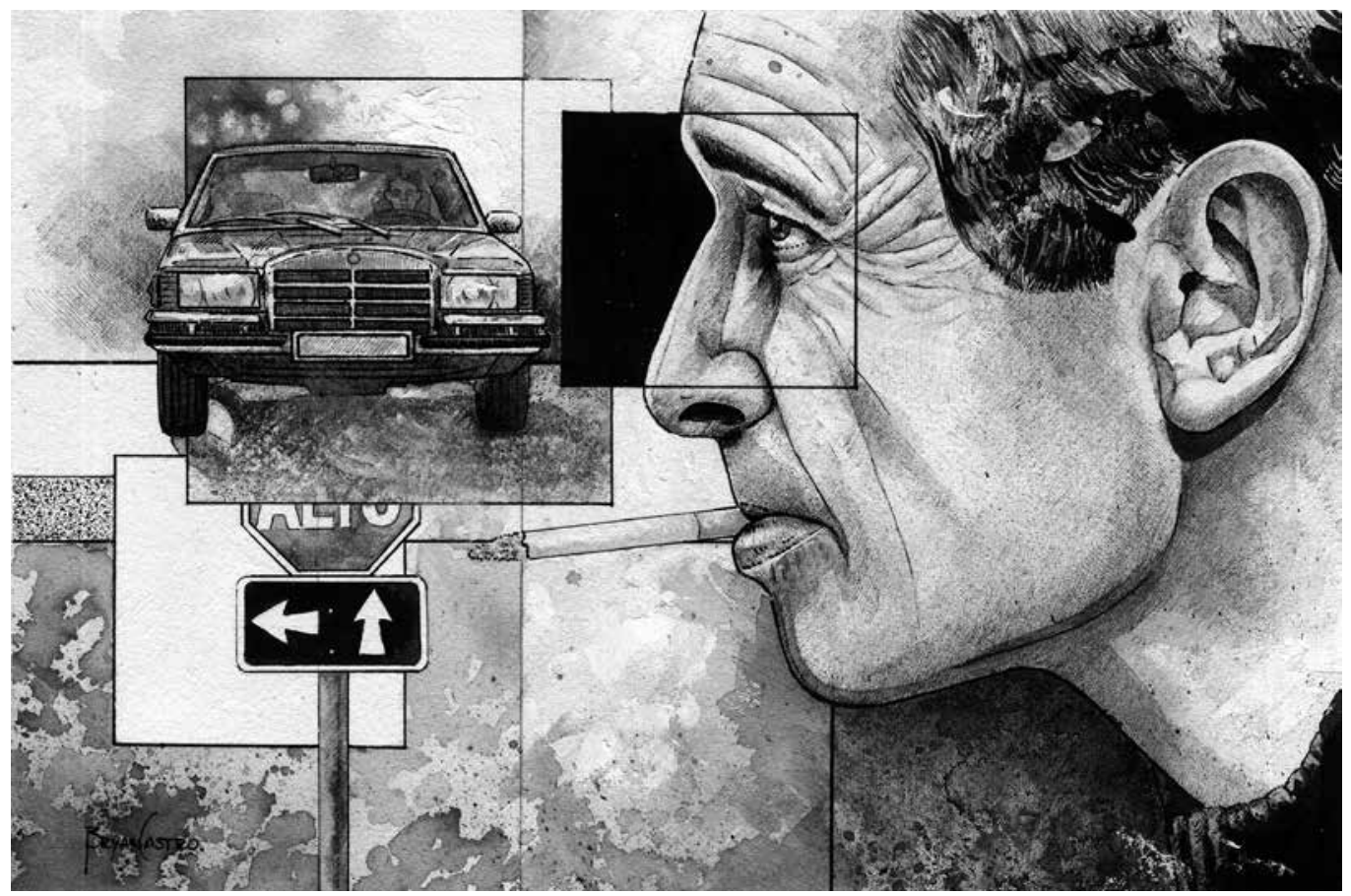

Bryan Castro Mora

El inglés platónico

Acuarela y grafito sobre papel $20 \times 32 \mathrm{~cm}$

2017 